\title{
Labour
}

Journal of Canadian Labour Studies

Le Travail

Revue d'Études Ouvrières Canadiennes

\section{Canadian Committee on Labour History, Annual General Meeting, 16 June 2020, Convened virtually from various locations across Turtle Island}

\section{Charles Smith et Joan Sangster}

Volume 86, automne 2020

URI : https://id.erudit.org/iderudit/1074498ar

DOI : https://doi.org/10.1353/1lt.2020.0062

Aller au sommaire du numéro

Éditeur(s)

Canadian Committee on Labour History

ISSN

0700-3862 (imprimé)

1911-4842 (numérique)

Découvrir la revue

Citer ce document

Smith, C. \& Sangster, J. (2020). Canadian Committee on Labour History, Annual

General Meeting, 16 June 2020, Convened virtually from various locations across Turtle Island. Labour / Le Travail, 86, 225-233.

https://doi.org/10.1353/llt.2020.0062 d'utilisation que vous pouvez consulter en ligne. 


\section{MINUTES / PROCÈS-VERBAL}

\section{Canadian Committee on Labour History}

Annual General Meeting

16 June 2020

Convened virtually from various locations across Turtle Island

The meeting was called to order at 12:03 pm Eastern Standard Time with CCLH President Kirk Niergarth in the Chair.

\section{ATTENDEES:}

Mikhail Bjorge, David Camfield, Edward Dunsworth, Alvin Finkel, David Frank, Rhonda Hinther, Ben Isitt (Secretary), Linda Kealey, Greg Kealey, Kathy Killoh, Robert Kristofferson, Kassandra Luciuk, Jeremy Milloy, James Naylor, Kirk Niergarth (President), Bryan Palmer, Jason Russell, Andrea Samoil, Joan Sangster, Charles Smith, Julia Smith.

\section{APPROVAL OF AGENDA}

It was moved by Greg Kealey, seconded by Bryan Palmer, that the agenda be adopted as presented.

Carried unanimously.

\section{APPROVAL OF MINUTES OF 2019 ANNUAL GENERAL MEETING}

It was moved by Rhonda Hinther, seconded by Charles Smith, that the minutes of the 2019 Annual General Meeting of the CCLH be adopted.

Carried unanimously.

\section{BUSINESS ARISING FROM THE MINUTES OF THE 2019 AGM}

The President provided an update on several items arising from the minutes of the previous year's Annual General Meeting, including progress toward making the CCLH website bilingual and the delay in launching the "Small Grants" pilot project. 
Alvin Finkel inquired about progress toward planning a labour history conference in 2021.

The President responded that a conference was being contemplated to take place at Simon Fraser University, and that it would likely be scheduled for 2022 in light of Covid-19 restrictions on public assemblies.

\section{PRESIDENT'S REPORT}

The President commented on the quality of submissions for the CCLH writing prizes and congratulated Edward Dunsworth on receiving the Eugene S. Forsey Doctoral Prize.

The President also commented on the desire to increase submissions for the CCLH undergraduate prize.

It was moved by Jim Naylor, seconded by Charles Smith, that the President's Report be adopted.

Carried unanimously.

\section{TREASURER'S REPORT}

The Treasurer reported on the work of the Ad Hoc CCLH Finance Committee, which had been formed during the previous year by the executive and consisted of Greg Kealey, Kirk Niergarth, Ben Isitt, Mikhail Borge, and Joan Sangster. The ad hoc committee had reported with the following recommendations, which were adopted by the CCLH Executive:

(1) to create a standing committee on finance, consisting of the Treasurer, President, and Co-Editors of Labour / Le Travail, to meet at least once per year and reporting to the CCLH Executive;

(2) to establish the following three accounts: (i) Publications Reserve Fund, at a level equivalent to five years expenditures; (ii) Special Projects Reserve Fund, at a level equivalent to 5 years expenditures; and (iii) Ongoing Operating Account, for ordinary operating expenditures; and

(3) that the CCLH Exec revisit the financial direction and planning for the CCLH every three years (in addition to annual financial planning and reporting processes).

The Treasurer reported on the annual financial statements of the CCLH, indicating that the CCLH was in a good financial position, with increased revenues from subscriptions and grants in 2019-2020. These increased revenues offset a modest increase in expenditures over the previous year. Overall, the CCLH saw a modest increase in financial reserves in 2019-2020. 
It was moved by Bryan Palmer, seconded by Alvin Finkel, that the Treasurer's Report be approved.

Carried unanimously.

\section{LABOUR / LE TRAVAIL REPORT}

Joan Sangster noted that two articles from the journal had been awarded with prizes, congratulating Kassandra Luciuk and Sonya Roy on their respective submissions and awards.

Joan Sangster noted that printing of the Spring 2020 issue of the journal would be delayed due to a delay at the printing press in Quebec arising from the Covid-19 pandemic.

Joan Sangster commented on submissions to the journal, indicating that a number of articles were currently at the revise and resubmit stage. Additional submissions from a historical perspective were also encouraged.

Joan Sangster indicated the desire to increase content relating to the journal on the new CCLH website.

Charles Smith indicated that francophone submissions to the journal remain consistent and healthy.

Charles Smith also indicated that the CCLH Editors and Athabasca University Press had discussed the feasibility of transitioning to an entirely electronic journal, with no decision on this matter having been made.

Greg Kealey commented on the high rate of submissions to the journal relative to other journals.

Charles Smith commented on the quality of submissions to the journal and the healthy balance of submissions from emerging and more established scholars.

Bryan Palmer suggested that the journal consider featuring a submission from the annual Forsey Prize winner, subject to a peer review process. Several members commented on this proposal, with approval.

It was moved by Edward Dunsworth, seconded by Andrea Samoil, that the Editors' Report approved.

Mikhail Borge inquired about the wisdom of transitioning toward an entirely digital edition of the journal, discontinuing a print edition. He indicated his support for retaining a print edition.

Jim Naylor indicated that the only rationale for discontinuing the print edition was financial, and that given the CCLH's strong financial position, this rationale did not currently apply to Labour / Le Travail. 
Kathy Killoh indicated that the CCLH could currently afford to continue with the print edition, while noting challenges with distribution of the Spring 2020 issue given Covid-19 work-from-home measures at Athabasca University Press, as well as delays with the printer. Kathy Killoh also commented on the structure of grants and subscriptions relating to the journal, including the provision for free online open access 12 months after the print edition was published.

Alvin Finkel proposed that the journal go to open (digital) access immediately upon publication (removing the 12-month delay), anticipating that the decline in subscription revenue would be marginal. Kathy Killoh indicated that grant funders would welcome this move, while noting a potential impact on revenues. Greg Kealey also commented on the potential financial impact in relation to revenues from databases and other sharing platforms, which amounted to approximately \$64,000 in 2019-2020.

Bryan Palmer, David Frank, Joan Sangster, Kirk Niergarth, and Julia Smith indicated their strong support for retaining the print edition of the journal. Julia Smith indicated the benefits of retaining the print edition from the standpoint of accessibility, including for members of the labour movement.

The motion was carried unanimously.

\section{SPECIAL RESOLUTION \#1: BYLAW AMENDMENT REGARDING EFFECTIVE DATE}

It was moved by Ben Isitt, seconded by Greg Kealey, that the following Special Resolution be adopted:

"That the CCLH Constitution and Bylaws be amended by adding a new Article IX, worded as follows:

Article Ix: Effective Date

This Constitution and Bylaws are effective June 17, 2020."

The motion carried unanimously.

\section{SPECIAL RESOLUTION \#2: BYLAW AMENDMENT REGARDING ASSOCIATIONS}

It was moved by Ben Isitt, seconded by Jim Naylor, that the following Special Resolution be adopted:

"That the CCLH Constitution and Bylaws be amended by revising Article III to read as follows:

Article III: Associations

The CCLH is an independent association affiliated with the Canadian Historical Association."

Carried unanimously. 
The President expressed appreciation to the secretary, Ben Isitt, for preparing the CCLH application for charitable status with the Canada Revenue Agency.

\section{EXECUTIVE MOTION: APPRECIATION FOR CCLH WORKSHOP ORGANIZING} It was moved by Kirk Niergarth, seconded by Bryan Palmer, that the following Executive motion be adopted:

"The CCLH thanks Miriam Wright for preparing the 2020 CCLH workshop 'Making Black History Public: Community-University Collaborations in Comics, Film, and Visual/Digital Creations' for the CHA meeting in London. This workshop was cancelled because of the pandemic."

Carried unanimously.

\section{EXECUTIVE MOTION: GRADUATE STUDENT THESIS RESEARCH AWARD}

The President and Treasurer introduced the concept of a new Graduate Student Thesis Research Award.

It was moved by Greg Kealey, seconded by Charles Smith, that the following resolution be adopted:

"The CCLH will create and offer the 'Canadian Committee on Labour History (CCLH) Graduate Student Thesis Research Award' beginning in 2021."

Julia Smith noted that the terms of reference for the award be revised to use the term "thesis", so that it is clear that work relating to Master's theses are eligible for the award. Joan Sangster suggested that the terms "theses" and "dissertations" both be used. Greg Kealey noted that eligibility should be confined to Master's theses and doctoral dissertations, but not extended to MA course work papers.

Carried unanimously.

\section{EXECUTIVE MOTION: RESTORATION OF FUNDING FOR DOCTORAL AND UNDERGRADUATE PRIZES}

It was moved by Kirk Niergarth, seconded by Jim Naylor, that the following resolution be adopted:

"The CCLH will restore funding to the Forsey Prizes, with $\$ 1000$ awarded in the graduate competition and $\$ 500$ in the undergraduate competition for the next three years."

Bryan Palmer suggested that the respective award amounts did not reflect the difference in labour required for a doctoral dissertation relative to an undergraduate paper. 
Julia Smith inquired into whether these annual expenditures were financially sustainable for the $\mathrm{CCLH}$, and suggested that lower amounts could be reasonable.

Joan Sangster indicated her support for a lower amount for the undergraduate prize, to move it more in line with $\mathrm{CHA}$ and institutional undergraduate scholarships.

Edward Dunsworth expressed support for retaining $\$ 500$ for the undergraduate prize to encourage submissions, and suggested that more generous awards could be a badge of honour for CCLH relative to other scholarship associations and institutions.

Jeremy Milloy, David Frank, and Alvin Finkel indicated support for generous award amounts, to encourage growth of the CCLH and the field of labour and working-class history.

Jason Russell suggested that any funds were better than no funds.

Julia Smith suggested that lowering the undergraduate award amount would allow for funds to be redeployed to other purposes, such as travel funding to support undergraduate attendance at Congress.

Julia Smith also pointed out that the reason for the low volume of submissions for the undergraduate prize was the limited course offerings in the field of labour and working-class history at postsecondary institutions.

Bryan Palmer moved an amendment, which was seconded by Julia Smith, to add the following language to the resolution:

"And that the CCLH executive review the monetary prizes including the amounts, as well as the volume and quality of submissions, over the next three years and report back to the membership."

The amendment carried unanimously.

The motion as amended carried unanimously.

\section{ADVERTISEMENT FOR COMMUNICATIONS ASSISTANT WITH HONORARIUM}

The President expressed appreciation to Christo Aivalis for his service as Social Media Coordinator for the CCLH.

The President moved, seconded that Kassandra Luciuk, that the following resolution be adopted:

"That the CCLH advertise for a Communications Assistant position and provide a monthly honorarium equivalent to the work involved in posting new content to the website and social media platforms." 
Jim Naylor inquired into whether this position would include rebuilding the website. The President clarified that this position would involve posting new content to the website and social media. The new website will be built by a contractor, as a distinct initiative from creating this Communications Assistant position.

The resolution was carried unanimously.

\section{ELECTIONS}

The President handed the chair over to the Second Vice-President, Mikhail Bjorge, to conduct elections for the following vacant officer positions on the CCLH Executive Committee:
a. President
b. First Vice President
c. Treasurer
d. Secretary
e. Social Media Co-ordinator

Mikhail Bjorge declared nominations open for the office of President of the CCLH.

Greg Kealey nominated Kirk Niergarth for the office of President of the CCLH. Kirk Niergarth agreed to stand. Mikhail Bjorge asked three more times for nominations. There being none, Mikhail Bjorge declared Kirk Niergarth acclaimed as President of the CCLH.

Mikhail Bjorge declared nominations open for the office of First-VicePresident of the CCLH.

Kirk Niergarth nominated Andrea Samoil for the office of First VicePresident of CCLH. Andrew Samoil agreed to stand. Mikhail Bjorge asked three more times for nominations. There being none, Mikhail Bjorge declared Andrew Samoil acclaimed as First Vice-President of the CCLH. Mikhail Bjorge declared nominations open for the office of Treasurer of the CCLH.

Kirk Niergarth nominated Greg Kealey for the office of Treasurer of the CCLH. Greg Kealey agreed to stand. Mikhail Bjorge asked three more times for nominations. There being none, Mikhail Bjorge declared Greg Kealey acclaimed as Treasurer of the CCLH.

Mikhail Bjorge declared nominations open for the office of Secretary of the CCLH. 
Kirk Niergarth nominated Ben Isitt for the office of Secretary of the CCLH. Ben Isitt agreed to stand. Mikhail Bjorge asked three more times for nominations. There being none, Mikhail Bjorge declared Ben Isitt acclaimed as CCLH Treasurer.

Mikhail Bjorge declared nominations open for the office of Social Media Coordinator of the CCLH.

Joan Sangster nominated Edward Dunsworth for the office of Social Media Coordinator of the CCLH. Edward Dunsworth declined to stand, expressing appreciation to his nominator. Mikhail Bjorge asked three more times for nominations. There being none, it was moved by Alvin Finkel, seconded by Charles Smith, that the CCLH Executive be empowered to undertake a search for a social media coordinator and fill the position until the next Annual General Meeting. The motion carried unanimously.

\section{OTHER BUSINESS}

The President asked members whether they had any other business to discuss.

Jim Naylor inquired about the prospects of convening a workshop at Congress in 2021, in light of the uncertainty arising from the pandemic.

Other members including Alvin Finkel and Julia Smith commented on the prospects of Congress convening in 2021.

Julia Smith noted that if Congress were to take place in 2021, there will likely be reduced participation because of economic circumstances, underscoring the benefits of providing for virtual participation.

The President asked for volunteers to serve on jury committees for CCLH Prizes, and the following members offered to serve:

-Edward Dunsworth

-Julia Smith

-Rhonda Hinther

-Bryan Palmer

-Jason Russell

-Kassandra Luciuk

Julia Smith expressed appreciation to the President, Kirk Niergarth, for organizing and convening a successful annual meeting. 
Kirk Niergarth expressed appreciation to Kassandra Luciuk and Mikhail Bjorge for coordinating technical aspects of the annual meeting.

\section{ADJOURNMENT}

The meeting adjourned at 1:45 pm, Eastern Standard Time. 